\title{
FOSTERING STUDENTS' VOCABULARY MASTERY THROUGH CHANGE A STORY GAME AT JUNIOR HIGH SCHOOL LEVEL
}

\author{
Juni Hartiwi *) \\ Juni_marvel@yahoo.com \\ Akademi Bahasa Asing (ABA) \\ Dian Cipta Cendikia Bandar Lampung
}

\begin{abstract}
Abstrak
Penelitian ini bertujuan untuk mengetahui pengaruh game Change The Story terhadap penguasaan kosa kata siswa dan nilai rata rata penguasaan kosa kata siswa yang telah belajar kosa kata melalui game Change The Story. Populasi dalam penelitian ini adalah siswa kelas VII SMPN 2 Jati Agung. Tes kosa kata digunakan untuk mengukur penguasaan kosa kata siswa. Hasil penelitian menunjukkan bahwa game Change The Story mempengaruhi penguasaan kosa kata siswa. Terlebih lagi, nilai rata rata kosa kata siswa meningkat setelah diberi perlakuan dengan menggunakan game Change The Story sebagai media pembelajaran kosa kata. Dengan kata lain, game ini berhasil memperbaiki penguasaan kosa kata siswa. Secara praktis game tersebut telah memberikan efek terapi kepada siswa, sehingga mereka dapat memperoleh banyak kosa kata dari pada sekadar merubah isi cerita secara global. Hal ini dapat menjadi satu hal yang menjanjikan bagi guru dan peneliti yang akan datang untuk lebih mengeksplorasi game ini pada keterampilan bahasa yang lain, disamping kosa kata sebagai komponen bahasa. Hal ini disebabkan oleh tugas guru untuk mampu memfasilitasi siswa dalam belajar. Tugas ini bisa dilakukan dengan cara memberdayakan strategi atau teknik yang tepat dan dengan menciptakan suasana belajar yang kondusif dimana pembelajaran dalam kelas dapat mereka rasakan seperti dunia mereka sendiri.
\end{abstract}

Kata kunci: Change a Story Game, penguasaan kosa kata

\section{INTRODUCTION}

In learning English, students have to learn about language skills. They are trained adequately in all four basic language skills; listening, speaking, reading and writing. These skills should be mastered by students by achieving the element of language vocabulary and appropriate grammar.
Vocabulary which is one of the important factors in understanding and using language can help students in listening, speaking, reading and writing. It would be impossible to learn English without vocabulary since we are unable to develop our language skills without vocabulary.

Thornbury (2002:13) stated that "Without grammar very little can be 
conveyed, without vocabulary nothing can be conveyed". It means that vocabulary is very important for communication in learning English. Without vocabulary we cannot master English well, because vocabulary as an aspect cannot be separated from learning language. In addition, Nunan (2003:138) also stated that "Using word parts to help remember words, and using guessing from context are to very important strategies for dealing with low frequency words". This can be inferred that both the words and appropriate strategies take an important role to assist the students in mastering the vocabulary.

To make students interested in learning English, a teacher should use the interesting teaching techniques in the classroom. A good situation can create for making students enjoy and also feel fun in the learning process. Giving the ice breaker with games also can help students to feel comfortable. Certainly the teacher should understand what the students' needs. Therefore, the students will feel fun, enjoy and comfortable for learning the materials from the teacher.

In her the preliminary research, the writer found that the students' vocabulary mastery needs to be increased. They found difficulties in mastering vocabulary. The students need much time to understand the meaning of vocabulary. In this occasion she also saw that the technique used by the English teacher less motivated students to learn vocabulary.

There are many techniques and media that can be used in teaching vocabulary, such as game, songs, picture, charts, audio, visual and audio-visual. Game is one of the teaching techniques that can be used in teaching process. It can make the lesson more interesting to learn and it is one of the ways to encourage students' motivation in learning English. The reason from the writer using game in teaching process is to motivate the students to increase their vocabulary. As we know that game is one of the interesting teaching techniques that can be applied in teaching learning process. It is interesting and it can make the students feel enjoy and feel fun when they learn the materials from the teacher.

Change the Story Game is one of the games that can be used in teaching vocabulary. Wright, David and Michael (2006: 119) claimed that "Change the Story Game is one of the games that can be used in teaching vocabulary. This game is an interesting game to increase their ability in making sentence and description. The teacher will ask them to make a description and then they will underline all the nouns and change all the nouns in their text to other noun." The statement shows that this game is very prospective and effective technique to assist the students in mastering 
vocabulary. It gives the students more space in exploring the words they are learning contextually.

In relation to the goals of the research, the writer focused on two goals; to know the influence of Change the Story Game toward students' vocabulary mastery and the average score of students' vocabulary mastery who learn vocabulary through Change the Story Game.

\section{METHOD}

This experimental research used two classes. The first class is as experimental class which were taught by using Change the Story Game and the second class was as control class which was not taught by using Change the Story Game at the same level. The result of the test both classes were compared to know the influence of students' vocabulary mastery taught by using Change the Story game. The subjects of the research were the students at the first semester of the eighth class at SMPN 2 Jati Agung Lampung Selatan in 2017/2018. The object of the research was students' vocabulary mastery. To know the students' vocabulary mastery the writer used the objective test that is multiple choice test consists of 50 items, each items consists of four options a, b, c and d. And the point of each item is 2 . So, the highest score is 100 and the lowest score is 0 .

\section{RESULT}

The teaching learning process of vocabulary was implemented through Change a Story game in which the writer as the teacher. Before starting the process of learning, students were given pre test to measure the students' prior vocabulary mastery. Later, the result of pre test would be compared with the result of post test. They would be calculated analyzed to know the influence of the technique and the average score of the students.

The implementation was done based on the procedure stated by Wright, David and Michael (2006:119). The procedure included some steps. First, it was by asking the learners to write a 70 -word short story or description, and to underline all the nouns in their text. You may wish to channel the learners' creativity by suggesting topic. Second is helping the class to compile a list of about twenty nouns through brainstorming. Last, it was by asking individual learners to read out their text, omitting the nouns. As they pause in place of a noun, the other learners supply a random noun from the list. Alternatively, each learner substitutes a noun at random into their text before reading it. The result can be very amusing, depending, of course, on comprehension of the word in context.

The score of students' vocabulary mastery that was taught through Change the Story game is called $\left(\mathrm{X}_{1}\right)$ which was done 
in experimental class. The score of students' vocabulary mastery that was taught through translation is called $\left(\mathrm{X}_{2}\right)$ which was done in control class. The result of the test hypothesis by using $\mathrm{t}_{\text {test }}=3.2$ and from the distribution table of $\mathrm{t}$ in the significant level of $5 \%$ known $\mathrm{t}_{\mathrm{tab}}=\mathrm{t}_{(1-1 / 2 \alpha)}$ $=1.67$ and $\mathrm{t}_{(1-\alpha)}=2.39$, and for the significant level of $1 \%$ known $\mathrm{t}_{\mathrm{tab}}=\mathrm{t}_{(1-1 / 2 \alpha)}$ $=1.67$ and $t_{(1-\alpha)}=2.39$. It means that $t_{\text {test }}>$

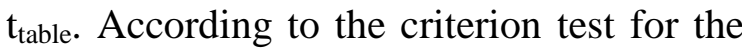
significant level of $5 \%$, Ho $1 \%$ is rejected. So that, it can be said that there is an influence of using Change The Story Game toward students' vocabulary mastery.

From the distribution list with $\mathrm{dk}=$ 70 , it was obtained the $t$ value for the $t_{0.95}$ and $t_{0.99}$ is 2.00 and 2.66. Because $t$ value is higher than value enlist of the students' distribution. So Ho2 is rejected and it can be concluded that the average score of the students' vocabulary mastery who were taught by using Change a Story Game is higher than that of those who are not taught using Change a Story game. In this case, the writer assumed that using Change The Story Game in teaching vocabulary is one of any alternative techniques in fostering the students' vocabulary.

\section{DISCUSSION}

As stated previously in the introduction, a game is needed to apply in teaching learning of a language. At the present research, the writer implemented Change a Story game to assist the students in improving students' vocabulary mastery. Harmer (1991:1) stated "Games are a vital part of teacher's equipments, not only for the language practice they provide, but also therapeutic effect they have. They can be used at any stage of a class to provide an amazing and challenging respite from another classroom activity, and are especially useful at the end of a long day to send the students away feeling cheerful about their English class". The statement means that a teacher should have considered to apply game in teaching a language. This is not only because it can equip students in doing the practice but also to give therapeutic effect to the student. This can bring the students into cheerful feeling in learning language, especially English.

Wright, David and Michael (2006:119) claimed that Change the Story Game is one of the games that can be used in teaching vocabulary. This game is an interesting game to increase their ability in making sentence and description. It means that teacher can play the role as facilitator more. She/he only asks the students to make a description and the students underline all the nouns and change the nouns into other kind of noun. This makes the writer to assume that this game really can provide the students to create a new 
ending story without missing the core of the story. By reading the whole story, the students already have an imagination what kind of story it will be on their hand. This can be done my changing the noun into other kind of noun which can create a new story.

In addition, Ralph Singh (2018) said that students want their studies to be relevant to their lives and feel they can have an impact on the world around them. Using Change the Story means that they can link project based learning to service learning to help solve some of the intractable problems of our times. His idea has made the writer thinks that Change the Story game is promising more assistance for the teacher to stimulate the students to learn. Besides giving the students chance to comprehend the story individually, this game can be linked with a group project to help solving problems appear about the story inside.

Related to the result of the research, the Change a Story game has successfully fostered the students to improve their vocabulary mastery. Practically it has given a therapeutic effect to the students, so that they can grasp many words to change instead of changing the story itself globally. This is promising for the teacher and other further researcher to explore more this game in other kind of skills of language, besides vocabulary as a component of a language, since the duty of a teacher is to facilitate the students to learn. This could be both by employing appropriate strategies or technique and by creating appropriate atmosphere where the learning class would be their own.

\section{CONCLUSION AND SUGGESTION}

\section{Conclusion}

The research reveals that there is an influence of Change a Story game toward students' vocabulary. In short, it can be concluded that Change a Story game can foster students' vocabulary mastery. The average score has an increase before and after the implementation of the game. It shows that this game is effective to help the students improving their vocabulary score in which it can assist them learning other skills of a language.

\section{Suggestion}

For the Teacher

Based on the conclusion above the writer would suggest the teacher to apply Change The Story game in teaching vocabulary to increase students'vocabulary mastery, because as the technique it will make the students' learning activities more fun and make them easier to understand the material. She/ he should also find other new strategies or technique for doing teaching in the classroom. 


\section{REFERENCE}

Harmer, Jeremy. (1991). The Practice of English Language Teaching. England: Longman Group Ltd

Nunan, David. (2003). Practical English language Teaching. Mc Graw-Hill. New York.

Richard, Jack C and Rodgers Theodore. (2001). Approaches and Methods in Language Teaching. UK. Cambridge University Press.

Thornbury, S. (2002). How To Teach Vocabulary. Pearson Education Limited. Edinbugh Gate. England

Wright, Andrew and David Betteridge and Michael Buckby. (2006). Games for Language Learning. Cambridge Handbooks for Language Teacher. Cambridge University Press.

http://www.wisdomthinker.org/change the story- a game to alter reality (november $12^{\text {th }} 2018$ ) 